\title{
Initial results of local strength analysis of a fiber concrete plate by 4-point bending tests
}

\author{
Oksana Goidyk ${ }^{1}$, Heiko Herrmann ${ }^{2}$ \\ Department of Cybernetics, School of Science, Tallinn University of Technology, Tallinn, Estonia \\ E-mail:2hh@cens.ioc.ee (corresponding author)
}

\begin{abstract}
The analysis of the post-cracking behavior of a large plate cast of fiber concrete shows a large variability due to the fiber alignment and dispersion. Therefore, one can expect, that the bending strength and other material parameters depend on the position in the plate. This means that the position the samples for testing are taken from may play a significant role in assessing the mechanical properties and strength of composite materials. Often, the investigation of fiber concrete properties have been performed by testing small size beams. The results can be influenced by the boundary restrictions, such as wall-effect, which influences the fiber distribution. In this study the four-point bending strength of beams cut out of a large plate was investigated, the results represent the local strength of the plate in this particular place. The fiber orientation and distribution have been evaluated by X-ray Computed Tomography and Image Analysis Method. The results of the experiments have shown that the position of the beam inside of a large-size plate has a strong influence on the mechanical properties and post-cracking behavior. The analysis of the obtained outcomes proposes the following conclusions: the beams that were located near the edges of the formwork have shown a strong, strain-hardening behavior, and the beams that were located on the way of the casting bucket (a zone of the high turbulence/perturbation/disturbance) have shown a weak, strain-softening behavior.
\end{abstract}

Keywords: fiber concrete, fiber orientation, fracture.

\section{Introduction}

In the modern building industry the majority of the fiber concrete applications are large structures, such as industrial floor plates, sewer and tunnel linings. Fiber reinforced structures with a life span of several centuries could be a significant benefit that reduces financial and environmental costs (Van Damme, 2018; Banthia, Bindiganavile, Jones, \& Novak, 2012). Thereby, it makes sense to investigate the mechanical properties and factors of improved strength of the large plates with the size comparable with the real life structures. While most studies focus on small laboratory samples, there have also been several studies have carried out experiments with large-size slabs and discussed the effect of fiber distribution and orientation on the post peak behavior (Zerbino, Tobes, Bossio, \& Giaccio, 2012; Žirgulis, Švec, Geiker, Cwirzen, \& Kanstad, 2016).

To increase the load-bearing capacity, reduce cracking formation and improve the tensile strength of large structures, short steel fibers can be inserted into a concrete matrix. Numerous studies have demonstrated advantages of short fibers embedded in composite materials (Holschemacher, Mueller, \& Ribakov, 2010; Laranjeira et al., 2012) compared to materials without fibers. Due to the ability of fibers to bridge the cracks and prevent their growing, and by that, ensure the durability and enhance the ductility of materials, many researchers have studied the properties of fibers and confirmed their efficiency in practice.

According to previous research (Kostrzanowska-Siedlarz \& Gołaszewski, 2016; Sebaibi, Benzerzour, \& Abriak, 2014; Herrmann \& Lees, 2016; Herrmann, Goidyk, \& Braunbrück, 2019b), the main factors which are important to take into account during the manufacturing process are:

- the mixing process (the constituents and proportions of the mixture, duration of the mixing process);

- the rheological properties of the obtained mixture (flow-ability, viscosity, homogeneous structure, segregation resistance);

- the casting process (pouring method: namely, the fixed casting position, or the casting point is moved in the longitudinal direction; the velocity of the casting process; the intervention in the pouring process the casting specialists in order to uniformly distribute and level the mixture in the formwork); 
- the geometry, size of the formwork and quality surface formwork (geometric wall-effect and roughness of the surface).

All aforementioned factors largely influence the position and orientation of the fibers in the concrete mass and thus, have an effect on the improvement of the mechanical properties of cementitious materials. Several scientists have shown the importance of uniform spatial fiber distribution, increasing of fiber content and the impact of proper dispersion of fibers on the ultimate flexural strength (Kang, Lee, J. K. Kim, \& Y. Y. Kim, 2011; Yoo, Yoon, \& Banthia, 2015; Zhou \& Uchida, 2017; Herrmann, Braunbrück, Tuisk, Goidyk, \& Naar, 2019a; Eik, Puttonen, \& Herrmann, 2016).

The orientation and distribution of the fibers have been estimated by numerous techniques: destructive and nondestructive character. The most common destructive methods for fiber distribution assessment are the slicing method with photometry (Eik et al., 2013), counting of the fibers on cuts (Gettu, Gardner, Saldivar, \& Barragán, 2005), destructive method with fiber orientation and distribution acquisition by X-ray Tomography (Wuest et al., 2009). Generally, the destructive techniques require the cutting of the samples into smaller pieces.

As an alternative, the non-destructive methods are widely used for fiber distribution and orientation. Among them the most popular techniques are X-ray Computed Tomography (Ponikiewski, Gołaszewski, Rudzki, \& Bugdol, 2015; Pastorelli \& Herrmann, 2016), electric (Al-Mattarneh, 2014; Ozyurt, Mason, \& Shah, 2006), magnetic (Faifer, Ottoboni, Toscani, \& Ferrara, 2010; Ferrara et al., 2017). The main benefits of this group of methods are high efficiency, safety, time-saving costs and accuracy.

In the present research, X-ray Computed Tomography is applied to estimate the fiber orientation and spatial distribution, Acoustic Emission (Soulioti et al., 2009) method to detect the first crack appearance, Scanning Electron Microscope to obtain the micro-structure of material and cohesion between cement matrix and fibers.

\section{Experimental setup}

During current experiments two large slabs with dimensions $(\mathrm{L} \times \mathrm{W} \times \mathrm{H}) 400 \mathrm{~cm} \times 100 \mathrm{~cm} \times 10 \mathrm{~cm}$ were cast, one of ordinary self-compacting concrete (SCC) and one of steel fiber reinforced self-compacting concrete (SFRSCC). For both slabs the bucket moving in the longitudinal direction was used as the pouring method. After the casting, the slabs were stored in the manufacturing hall for curing and hardening at room temperature. Hereinafter the hardened slabs were cut into smaller beams. Specifically, from the slab of ordinary concrete 10 beams of dimensions $100 \mathrm{~cm} \times 9.5 \mathrm{~cm} \times$ $10 \mathrm{~cm}$ have been cut out and the slab of fiber concrete has been cut into 40 beams of size $100 \mathrm{~cm} \times 9.5 \mathrm{~cm} \times 10 \mathrm{~cm}$. A principal disposition of the specimens is depicted in Figure 1 and a detailed description of the experimental setup can be found in (Herrmann, Goidyk, Naar, Tuisk, \& Braunbrück, 2019c).
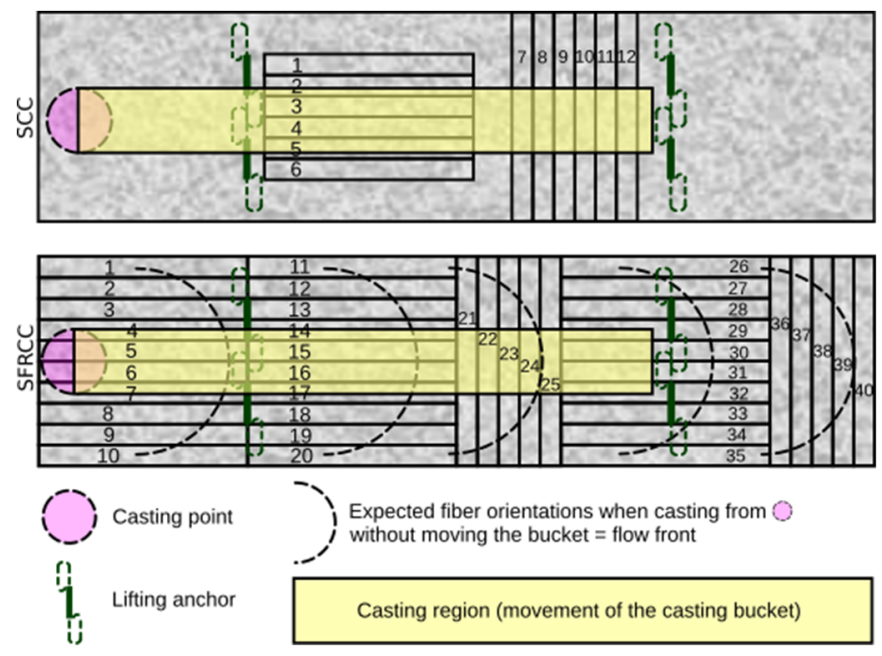

Figure 1. Layout of the beam-cutting in the plates; image reproduced from (Herrmann et al., 2019c)

To analyze the difference between the mechanical properties of beams taken from different positions of a large slab, 4-point bending tests were performed by using the universal hydraulic bending machine EU100, as shown in Figure 2. The testing beams were maintained with two roller supports on the distance of $90 \mathrm{~cm}$, and $5 \mathrm{~cm}$ from each supports to the edges of the specimens. The load was distributed through the load cell HBM U10M and two loading points that were located at the distance $15 \mathrm{~cm}$ from the vertical axis of the load cell. To measure the vertical deflections under the load two displacement transducers $H B M W I / 10 m m-T$ were used. To record the experimental data and control the testing procedure an HBM QuantumX MX840A universal measuring amplifier module and a laptop were used. To collect and visualize the obtained data the CatmanEasy $D A Q$ software was applied. 


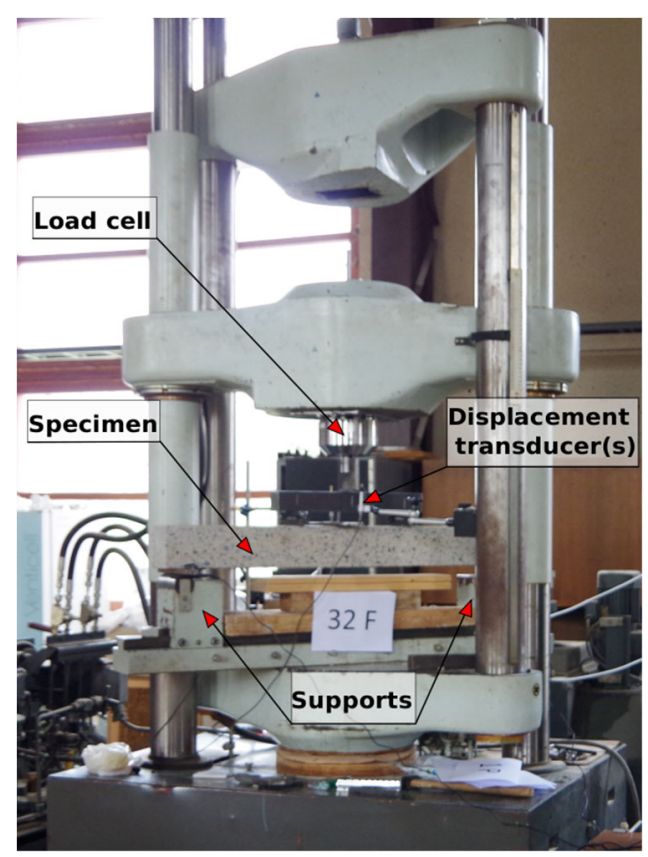

Figure 2. The bending testing machine

The force-displacement curves that were obtained by the analysis of the data after the four-point bending tests of the SFRSCC beams are presented in Figure 3.

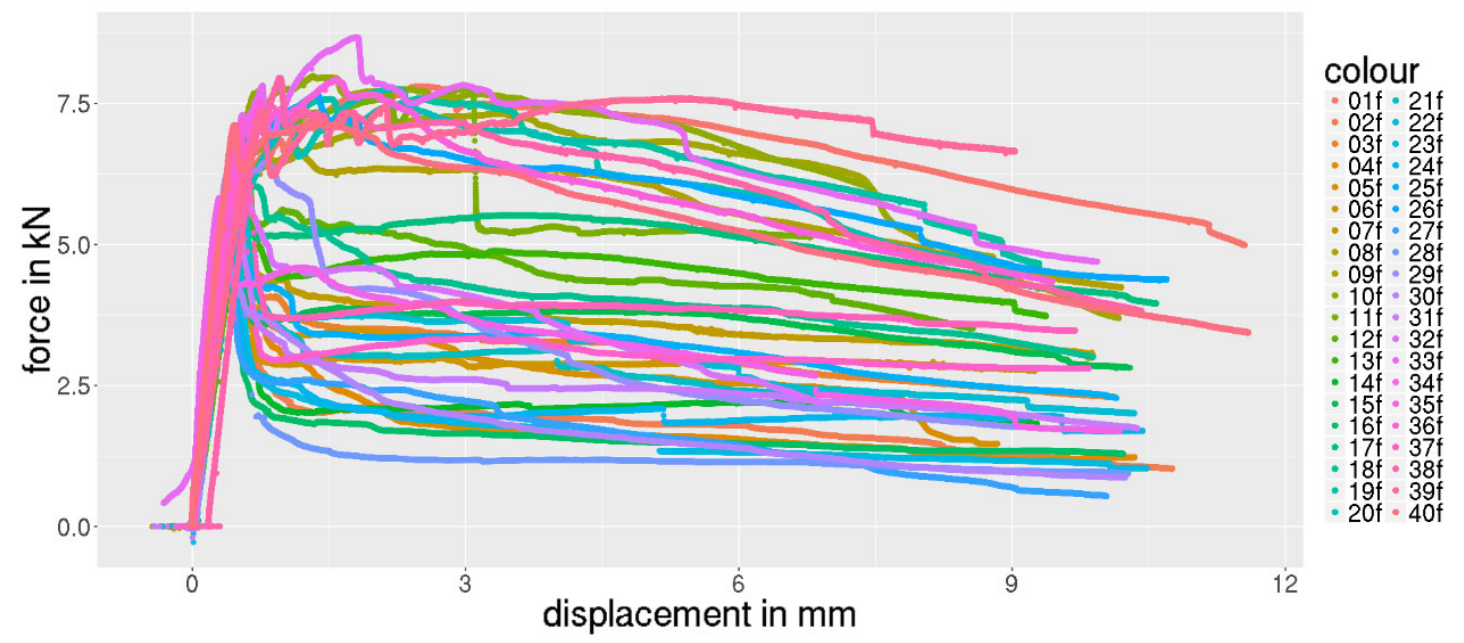

Figure 3. Force-displacement curves of the four-point bending tests for all fiber-beams; image reproduced from (Herrmann et al., 2019c)

\section{Results and conclusions}

The SCC beams behaved brittle as expected with little variation of the maximum load and displacement. The diagram for the SCC beams can be found in Herrmann et al. (2019c). Figure 3 shows the force-displacement curves of the fourty tested fiber-concrete beams, the curves show a large variability in the post-cracking behavior. The fibers introduced some ductility to the concrete. However, the behavior range includes almost brittle, where the residual load-bearing capacity drops to less than a quarter of the load at first crack, up to slightly strain-hardening, where the post-cracked load-bearing reaches a peak that is higher than the load at first crack. Specifically, the beams taken from the edges of the slab show mainly the strain-hardening behavior, where the maximum load is higher than the load at the first crack. Whereas, the beams taken from the central positions on the way of the moving bucket, represent mainly the strainsoftening behavior, where the residual strength is only a quarter of the load at first crack.

To examine the influence of fiber orientation and distribution in the beams on the post-cracking behavior X-ray Computed Tomography scanning of selected beams is being carried out. The correlation between fiber orientations and post-cracking behavior will be obtained in the nearest investigations. Preliminary inspection of the edge beam 
scanned until now shows visually a very good alignment of the fibers in tensile stress direction in the bottom layer of the plate, which has to cope with the highest tensile stress.

\section{Acknowledgements}

This work was supported by the Estonian Research Council grant (PUT1146). Support by a BALTECH scholarship for attending MBMST conference for H.H. is gratefully acknowledged.

The authors thank AS E-Betoonelement for preparing the experiment plates, space for cutting the beams and their general interest in the research. Further, the authors thank Andres Braunbrück for helping with the experiments.

\section{References}

Al-Mattarneh, H. (2014). Electromagnetic quality control of steel fiber concrete. Construction and Building Materials, 73, 350-356. https://doi.org/10.1016/j.conbuildmat.2014.09.101

Banthia, N., Bindiganavile, V., Jones, J., \& Novak, J. (2012). Fiber-reinforced concrete in precast concrete applications: Research leads to innovative products. PCI Journal, 57(3). https://doi.org/10.15554/pcij.06012012.33.46

Eik, M., Lõhmus, K., Tigasson, M., Listak, M., Puttonen, J., \& Herrmann, H. (2013). DC-conductivity testing combined with photometry for measuring fibre orientations in SFRC. Journal of Materials Science, 48(10), 3745-3759. https://doi.org/10.1007/s10853-013-7174-3

Eik, M., Puttonen, J., \& Herrmann, H. (2016). The effect of approximation accuracy of the orientation distribution function on the elastic properties of short fibre reinforced composites. Composite Structures, 148, 12-18. https://doi.org/10.1016/j.compstruct.2016.03.046

Faifer, M., Ottoboni, R., Toscani, S., \& Ferrara, L. (2010, May). Steel fiber reinforced concrete characterization based on a magnetic probe. In 2010 IEEE Instrumentation \& Measurement Technology Conference Proceedings (pp. 157-162). IEEE. https://doi.org/10.1109/IMTC.2010.5488179

Ferrara, L., Cremonesi, M., Faifer, M., Toscani, S., Sorelli, L., Baril, M. A., Réthoré, J., .., \& Bernardi, S. (2017). Structural elements made with highly flowable UHPFRC: Correlating computational fluid dynamics (CFD) predictions and nondestructive survey of fiber dispersion with failure modes. Engineering Structures, 133, 151-171. https://doi.org/10.1016/j.engstruct.2016.12.026

Gettu, R., Gardner, D. R., Saldivar, H., \& Barragán, B. E. (2005). Study of the distribution and orientation of fibers in SFRC specimens. Materials and Structures, 38(1), 31-37. https://doi.org/10.1007/BF02480572

Herrmann, H., \& Lees, A. (2016). On the influence of the rheological boundary conditions on the fibre orientations in the production of steel fibre reinforced concrete elements. Proceedings of the Estonian Academy of Sciences, 65(4), 408. https://doi.org/10.3176/proc.2016.4.08

Herrmann, H., Braunbrück, A., Tuisk, T., Goidyk, O., \& Naar, H. (2019a). An initial report on the effect of the fiber orientation on the fracture behavior of steel fiber reinforced self-compacting concrete. In Short fibre reinforced cementitious composites and ceramics (pp. 33-50). Springer, Cham. https://doi.org/10.1007/978-3-030-00868-0_3

Herrmann, H., Goidyk, O., \& Braunbrück, A. (2019b). Influence of the flow of self-compacting steel fiber reinforced concrete on the fiber orientations, a report on work in progress. In Short Fibre Reinforced Cementitious Composites and Ceramics (pp. $97-$ 110). Springer, Cham. https://doi.org/10.1007/978-3-030-00868-0_7

Herrmann, H., Goidyk, O., Naar, H., Tuisk, T., \& Braunbrück, A. (2019c). The influence of fiber orientation in self-compacting concrete on 4-point bending strength. Proceedings of the Estonian Academy of Sciences, 68(3) (forthcoming) (CC BY-NC 4.0). https://doi.org/10.3176/proc.2019.3.12

Holschemacher, K., Mueller, T., \& Ribakov, Y. (2010). Effect of steel fibres on mechanical properties of high-strength concrete. Materials \& Design, 31(5), 2604-2615. https://doi.org/10.1016/j.matdes.2009.11.025

Kang, S. T., Lee, B. Y., Kim, J. K., \& Kim, Y. Y. (2011). The effect of fibre distribution characteristics on the flexural strength of steel fibre-reinforced ultra high strength concrete. Construction and Building Materials, 25(5), 2450-2457. https://doi.org/10.1016/j.conbuildmat.2010.11.057

Kostrzanowska-Siedlarz, A., \& Gołaszewski, J. (2016). Rheological properties of high performance self-compacting concrete: effects of composition and time. Construction and Building Materials, 115, 705-715. https://doi.org/10.1016/j.conbuildmat.2016.04.027

Laranjeira, F., Aguado, A., Molins, C., Grünewald, S., Walraven, J., \& Cavalaro, S. (2012). Framework to predict the orientation of fibers in FRC: a novel philosophy. Cement and Concrete Research, 42(6), 752-768. https://doi.org/10.1016/j.cemconres.2012.02.013

Ozyurt, N., Mason, T. O., \& Shah, S. P. (2006). Non-destructive monitoring of fiber orientation using AC-IS: An industrial-scale application. Cement and Concrete Research, 36(9), 1653-1660. https://doi.org/10.1016/j.cemconres.2006.05.026

Pastorelli, E., \& Herrmann, H. (2016). Time-efficient automated analysis for fibre orientations in steel fibre reinforced concrete. Proceedings of the Estonian Academy of Sciences, 65(1), 28. https://doi.org/10.3176/proc.2016.1.02

Ponikiewski, T., Gołaszewski, J., Rudzki, M., \& Bugdol, M. (2015). Determination of steel fibres distribution in self-compacting concrete beams using X-ray computed tomography. Archives of Civil and Mechanical Engineering, 15(2), 558-568. https://doi.org/10.1016/j.acme.2014.08.008 
Sebaibi, N., Benzerzour, M., \& Abriak, N. E. (2014). Influence of the distribution and orientation of fibres in a reinforced concrete with waste fibres and powders. Construction and Building Materials, 65, 254-263. https://doi.org/10.1016/j.conbuildmat.2014.04.134

Soulioti, D., Barkoula, N. M., Paipetis, A., Matikas, T. E., Shiotani, T., \& Aggelis, D. G. (2009). Acoustic emission behavior of steel fibre reinforced concrete under bending. Construction and Building Materials, 23(12), 3532-3536. https://doi.org/10.1016/j.conbuildmat.2009.06.042

Van Damme, H. (2018). Concrete material science: past, present, and future innovations. Cement and Concrete Research, 112, 524. https://doi.org/10.1016/j.cemconres.2018.05.002

Wuest, J., Denarié, E., Brühwiler, E., Tamarit, L., Kocher, M., \& Gallucci, E. (2009). Tomography analysis of fiber distribution and orientation in ultra high - performance fiber-reinforced composites with high-fiber dosages. Experimental Techniques, 33(5), 50-55. https://doi.org/10.1111/j.1747-1567.2008.00420.x

Yoo, D. Y., Yoon, Y. S., \& Banthia, N. (2015). Flexural response of steel-fiber-reinforced concrete beams: Effects of strength, fiber content, and strain-rate. Cement and Concrete Composites, 64, 84-92. https://doi.org/10.1016/j.cemconcomp.2015.10.001

Zerbino, R., Tobes, J. M., Bossio, M. E., \& Giaccio, G. (2012). On the orientation of fibres in structural members fabricated with self compacting fibre reinforced concrete. Cement and Concrete Composites, 34(2), 191-200. https://doi.org/10.1016/j.cemconcomp.2011.09.005

Zhou, B., \& Uchida, Y. (2017). Relationship between fiber orientation/distribution and post-cracking behaviour in ultra-highperformance fiber-reinforced concrete (UHPFRC). Cement and Concrete Composites, 83, 66-75. https://doi.org/10.1016/j.cemconcomp.2017.07.007

Žirgulis, G., Švec, O., Geiker, M. R., Cwirzen, A., \& Kanstad, T. (2016). Influence of reinforcing bar layout on fibre orientation and distribution in slabs cast from fibre - reinforced self - compacting concrete (FRSCC). Structural Concrete, 17(2), 245256. https://doi.org/10.1002/suco.201500064 